\title{
FUNGSI PENGAWASAN DEWAN PERWAKILAN RAKYAT DAERAH TERHADAP PELAKSANAAN ANGGARAN PENDAPATAN DAN BELANJA DAERAH
}

\section{OVERSIGHT RIGHT OF REGIONAL HOUSE OF REPRESENTATIVES (DPRD) TO THE IMPLEMENTATION OF REGIONAL INCOME AND EXPENDITURE BUDGET}

Bawon Nul Hakim

bawonnulhakim@gmail.com

Prodi D-III Kebidanan, STIKes Hafshawaty Pesantren Zainul Hasan

\begin{abstract}
ABSTRAK
Pengawasan terhadap pengelolaan APBD yang dilakukan oleh DPRD merupakan hak setiap anggota DPRD dalam rangka memperjuangkan kepentingan masyarakat, termasuk di daerah pemilihannya. APBD merupakan rencana keuangan pemerintahan daerah yang disetujui oleh DPRD dan ditetapkan dengan peraturan daerah. Maka dalam Pelaksanaan APBD agar tidak terjadi penyimpangan dan penyelewengan anggaran, diperlukan adanya pengawasan yang kuat. Pengawasan DPRD terhadap APBD tidak hanya terbatas pada penggunaan anggaran tetapi juga pada sisi pemasukan dan pendapatan. Metode penelitian yang di gunakan dalam penelitian ini adalah penelitian yuridis empiris yaitu pendekatan yang dilakukan dengan melihat bagaimana hukum yang ada dalam Undang-Undang diterapkan dalam lembaga legislatif melalui observasi. Beberapa kendala dan hambatan yang dialami oleh DPRD Kabupaten Probolinggo salah satunya adalah kurangnya sumber daya manusia yang ahli dalam hal pengawasan terhadap APBD. Faktor lain yang menjadi penghambat adalah kurangnya melibatkan partisipasi aktif dari masyarakat dalam penyusunan dan pengawasan APBD, sehingga kebutuhan masyarakat sering terabaikan. Tetapi untuk meminimalisasikan penghambat dalam proses pembangunan system pengawasan yang dilakukan oleh DPRD kabupeten Probolinggo, DPRD memiliki suatu perangkat yaitu komisi-komisi sesuai bidangnya, selain komisi DPRD kabupaten Probolinggo juga membentuk Panitia Khusus apabila ada permasalahan yang mendesak dalam rangka pengawasan.
\end{abstract}

Kata Kunci : Pengawasan, APBD, DPRD

\section{ABSTRACT}

Supervision of the management of the regional budget carried out by the DPRD is the right of each member of the DPRD in the context of fighting for the interests of the community, including in their constituencies. APBD is a regional government financial plan that is approved by the DPRD and stipulated by regional regulations. Therefore, a strong supervision is needed to avoid deviations and 
misappropriation of the budget,. Parliamentary oversight of the APBD is not only limited to the use of the budget but also on the income and revenue side. The research method used in this study is empirical juridical research, an approach carried out by looking at how the existing law in the Act is applied in the legislative body through observation. There are some obstacles experienced by the Probolinggo District Legislative Council, one of which is the lack of skilled human resources in overseeing the APBD. Another obstacle is the lack of active participation from the community in the preparation and supervision of the regional budget, so that community needs are often overlooked. However, to minimize obstacles in the process of developing a monitoring system conducted by the Probolinggo Regency DPRD, the DPRD has a set of commissions according to their fields, in addition to the Probolinggo district DPRD commission also forms a Special Committee if there are pressing issues in the framework of supervision.

Keywords: Supervision, APBD, DPRD

\section{PENDAHULUAN}

Sejak otonomi daerah diberlakukan, pemerintah daerah memiliki beban untuk mempercepat laju pertumbuhan dan pembangunan daerah, mensejahterakan, menyerap dan menjalankan harapan masyarakat (Komarudin, 2008). Dewan Perwakilan Rakyat Daerah (DPRD) merupakan mitra Kepala Daerah dalam merumuskan semua kebijakan untuk menjalankan roda pemerintahan di daerah, keduanya merupakan lembaga yang memiliki kedudukan sejajar dalam sistem pemerintahan di Indonesia yang memiliki kewenangan untuk menghasilkan berbagai kebijakan dan membentuk peraturan daerah mengenai Anggaran Pendapatan dan Belanja Daerah.

Kewenangan lain yang dimiliki oleh DPRD sebagaimana diamanatkan Undang-Undang Republik Indonesia Nomor 17 Tahun 2014 adalah melaksanakan pengawasan terhadap pelaksanaan peraturan daerah dan Anggaran Pendapatan dan Belanja Daerah (APBD), yang telah dibuat bersama dengan Kepala Daerah.

Di dalam penjelasan umum undang undang tersebut diterangkan bahwa pengawasan terhadap pengelolaan APBD yang dilakukan oleh DPRD merupakan hak setiap anggota DPRD dalam rangka memperjuangkan kepentingan masyarakat, termasuk di daerah pemilihannya. APBD pada prinsipnya sama 
dengan APBN yang membutuhkan pengawasan secara internal dan eksternal, pengawasan eksternal dilakukan oleh DPRD dan BPK, sedangkan pengawasan internal dilaksanakan oleh pemerintah daerah dan jajarannya.

APBD merupakan perwujudan amanat rakyat kepada pemerintah melalui Dewan Perwakilan Rakyat Daerah (DPRD) dalam meningkatkan kesejahteraan masyarakat dan pelayanan kepada masyarakat, APBD juga merupakan rencana keuangan tahunan pemerintahan daerah yang disetujui oleh DPRD dan ditetapkan dengan peraturan daerah. Maka dalam Pelaksanaan APBD agar tidak terjadi penyimpangan dan penyelewengan anggaran, diperlukan adanya pengawasan yang kuat (Soekarwo, 2003).

Pengawasan dewan terhadap APBD tidak hanya terbatas pada penggunaan anggaran tetapi juga pada sisi pemasukan dan pendapatan. Agar pemerintah terdorong untuk melaksanakan tugas perolehan pendapatan daerah (Inosentius, 2006). Akan tetapi yang akan menjadi titik persoalan, apakah pengawasan dari Anggaran Pendapatan dan Belanja Daerah (APBD) tersebut sesuai dengan pelaksanaan otonomi daerah (sesuai dengan Undang-Undang Negara Republik Indonesia Nomor 32 Tahun 2004 yang diperbarui dengan Undang-Undang Nomor 23 Tahun 2014 Tentang Pemerintahan Daerah), sehingga tercapai optimalisasi Pendapatan Asli Daerah (PAD) yang seimbang dengan pengeluaran daerah yang tepat untuk keperluan-keperluan daerah, infrastruktur, pembangunan daerah, dan lain-lainnya.

Berdasarkan uraian tersebut, maka penulis tertarik untuk mengadakan penelitian tentang "Peran DPRD kabupaten Probolinggo dalam upaya optimalisasi pelaksanaan APBD pada tahun 2017. Jika dilihat bahwa DPRD dalam melaksanakan haknya sebagai implementasi dari tugas legislasinya dalam pelaksanaan otonomi daerah sebelum sepenuhnya terealisasi secara maksimal.

\section{METODE PENELITIAN}

Metode yang di gunakan dalam penelitian ini adalah penelitian yuridis empiris yaitu pendekatan yang dilakukan dengan melihat bagaimana hukum yang 
ada dalam Undang-Undang diterapkan dalam lembaga legislatif kabupaten Probolinggo melalui observasi.

\section{HASIL PENELITIAN DAN PEMBAHASAN}

Konsepsi pengawasan DPRD meliputi pemahaman tentang makna dan arti penting pengawasan, ruang lingkup dan proses pengawasan (Aminudin, 2015). Dalam konteks membangun manajemen pemerintahan publik yang bercirikan good governance, pengawasan merupakan salah satu fungsi manajemen untuk menjamin pelaksanaan kegiatan sesuai dengan kebijakan dan rencana yang telah ditetapkan serta memastikan tujuan dapat tercapai secara efektif dan efisien. melakukan pengawasan sangat diperlukan untuk menghindari adanya kemungkinan penyelewengan dan penyimpangan atas tujuan yang akan dicapai. Bahkan melalui pengawasan dapat tercipta suatu aktivitas yang berkaitan erat dengan penentuan atau evaluasi mengenai sejauhmana pelaksanaan kinerja sudah terlaksana. Controlling is the process of measuring performance and taking action to ensure desired results (Schermerhorn, 2002)

Menurut George R. Tery, pengawasan adalah determinasi apa yang telah dilaksanakan, mengevaluasi prestasi kerja dan menerapkan tindakan-tindakan korektif, sehingga hasil pekerjaan sesuai dengan rencana yang telah ditetapkan. The process of ensuring that actual activities conform the planned activities (Stoner, Freeman \& Gilbert, 2005).

Ruang lingkup pengawasan yang dilakukan oleh DPRD meliputi seluruh siklus anggaran, mulai dari tahap perencanaan, pelaksanaan, dan pengawasan. DPRD memastikan bahwa siklus anggaran dilaksanakan sesuai dengan peraturan perundang-undangan yang berlaku dan berorientasi pada prioritas publik.

Dijelaskan dalam Peraturan Pemerintah Nomor 58 tahun 2005 tentang Pengelolaan Keuangan Daerah pada Pasal 132 DPRD melakukan pengawasan, tetapi bukan merupakan bentuk pemeriksaan (auditor) pengeloalaan dan pertanggungjawaban APBD namun lebih mengarah pada pengawasan untuk 
menjamin pencapaian sasaran yang telah ditetapkan dalam dokumen perencanaan dan penganggaran. terhadap pelaksanaan

Dengan adanya fungsi pengawasan yang diberikan kepada DPRD Kabupaten Probolinggo dalam hal anggaran khususnya, maka DPRD Kabupaten Probolinggo memiliki wewenang untuk memberikan masukan dan saran agar tidak terjadi penyimpangan anggaran yang dilakukan oleh pemerintah daerah, sehingga pemerintahan dapat dikendalikan dengan baik, demi membangun Kabupaten Probolinggo menjadi kabupaten yang gotong royong.

Tugas dan wewenang DPRD melaksanakan pengawasan terhadap pelaksanaan APBD terdapat dalam Undang-undang Nomor 17 Tahun 2014 tentang MPR, DPD, DPR, DPRD dan juga tertuang dalam pasal 42 huruf $\mathrm{c}$ Undang-Undang Negara Republik Indonesia Nomor 32 Tahun 2004 Tentang Pemerintahan Daerah. Pengawasan atas pelaksanaan APBD dilakukan oleh DPRD, untuk menjamin pencapaian sasaran yang telah ditetapkan dikelompokkan pada tahap perencanaan, tahap pelaksanaan APBD, dan tahap pertanggungjawaban.

\section{Tahap Perencanaan}

Pada tahap pertama pengawasan APBD yang dilakukan DPRD dimulai dari tahap perencanaan. Pada tahap pertama ini pemerintah daerah bersama DPRD menyusun arah dan kebijakan umum APBD, diawali dengan penjaringan aspirasi masyarakat, berpedoman pada rencana strategis daerah dan dokumen perencanaan lainya yang ditetapkan daerah, serta pokok-pokok kebijakan nasional dibidang keuangan daerah oleh Menteri Dalam Negeri. Berdasarkan arah dan kebijakan umum APBD tersebut kepala daerah menyusun strategi dan prioritas APBD. Pada tahap ini DPRD memiliki peran dalam menampung aspirasi dan masukan dari semua lapisan masyrakat, untuk dijadikan bahan rujukan dan petunjuk bagi DPRD untuk menentukan strategi dan prioritas dari APBD tersebut.

Pelaksanaan Pengawasan yang dilakukan oleh DPRD dalam tahap perencanaan APBD Kabupaten Probolinggo sudah dilakukan, karena tahap 
perencanaan ini adalah awal terbentuknya APBD yang akan dianggarkan oleh pemerintah daerah untuk kepentingan kesejahteraan masyarakat.

\section{Tahap Pelaksanaan}

Pada tahap pelaksanaan fungsi pengawasan yang dilakukan oleh DPRD terhadap pengelolaan APBD Kabupaten Probolinggo, meliputi beberapa cara dalam pelaksanaannya, diantaranya adalah

1) Pembentukan alat kelengkapan DPRD, yang terdiri dari:

a) Pimpinan DPRD

Pimpinan DPRD merupakan lembaga yang bersifat kolektif, yang terdiri dari ketua dan wakil-wakil ketua yang dipilih dari dan oleh anggota DPRD, pimpinan DPRD terdiri atas unsur fraksi dalam DPRD, pimpinan DPRD memiliki masa kerja selama 5 tahun.

b) Badan Anggaran

Badan Anggaran adalah merupakan alat kelengkapan DPRD yang bersifat tetap dan dibentuk oleh DPRD pada awal masa jabatan keanggotaan DPRD. Salah satu tugas Badan Anggaran adalah memberikan saran dan pendapat berupa pokokpokok pikiran DPRD kepada kepala daerah dalam mempersiapkan RAPBD, melakukan pembahasan bersama tim anggaran pemerintah daerah terhadap rancangan kebijakan umum APBD, memberikan saran kepada pimpinan DPRD dalam penyususnan anggaran belanja DPRD.

c) Badan Musyawarah

Badan Musyawarah merupakan alat kelengkapan DPRD yang bersifat tetap dan dibentuk oleh DPRD pada awal masa jabatan keanggotaan DPRD, susunan keanggotaan Badan Musyawarah ditetapkan dalam rapat paripurna setelah terbentuknya Pimpinan DPRD, Komisi, Badan Anggaran, dan Fraksi.

Badan Musyawarah memiliki peran penting dalam melaksanakan pengawasan Anggaran di Kabupaten Probolinggo, karena Badan Musyawarah memiliki tugas dalam menetapkan waktu.

d) Komisi-Komisi Sebagai Pelaksana Pengawasan APBD 
Komisi adalah alat kelengkapan DPRD yang dibentuk oleh pimpinan DPRD untuk menangani bidang tugas umum tertentu.Anggota komisi terdiri atas unsur fraksi, adapun masa kerja komisi paling lama 2 tahun.

DPRD Kabupaten Probolinggo memiliki empat Komisi, masing-masing: Komisi A (Menangani Bidang Pemerintahan); Komisi B (Menangani Bidang Ekonomi); Komisi C (Menangani Bidang Pembangunan dan Anggaran); Komisi D (Menangani Bidang Pendidikan, Keagamaan dan Kesra).

Dalam melasanakan pengawasan APBD di Kabupaten Probolinggo, DPRD Kabupaten Probolinggo mengandalkan atau menjadikan komisi-komisi sebagai ujung tombak dalam melaksanakan pengawasan terhadap pengelolaan APBD.

Dalam wawancara dengan Wakil Ketua DRPD Kabupaten Probolinggo, Drs. H. Wahid Nurrahman, M.Si beliau mengatakan bahwa komisi adalah ujung tombak yang diandalkan dalam pengawasan pengelolaan APBD di Kabupaten Probolinggo, upaya yang harus dilakukan oleh setiap komisi agar berjalan dengan baik adalah turun langsung kepada masyarakat guna menyerap aspirasi secara langsung dari masyarakat dan mendapatkan data-data tentang penyimpangan anggaran yang dilakukan oleh lembaga eksekutif.

e) Badan Legislasi Daerah

Badan Legislasi Daerah merupakan alat kelengkapan DPRD yang bersifat tetap, dibentuk dalam rapat paripurna DPRD, pimpinan Badan Legislasi Daerah terdiri dari satu orang ketua, satu orang wakil ketua yang dipilih dari dan oleh anggota Badan Legislasi Daerah berdasarkan prinsip musyawarah untuk mufakat. Adapun anggota Badan Legislasi Daerah diusulkan dari masing-masing fraksi.

Dalam melaksanakan pengawasan terhadap anggaran, karena Badan Legislasi telah melakukan tugasnya dalam membuat semua peraturan-peraturan tentang anggaran dan juga dijadikan sebagai pedoman pelaksanaan anggaran, kemudian melakukan pengawasan APBD yang berpedoman kepada peraturan yang telah dibuat. 
f) Alat Kelengkapan Lain yang Diperlukan dan Dibentuk Oleh Paripurna.

Alat kelengkapan khusus contohnya adalah panitia khusus, panitia khusus sebagai alat kelengkapan DPRD yang dibentuk untuk menangani tugas yang bersifat khusus, anggota panitia khusus terdiri atas unsur-unsur fraksi.

2) Serap Aspirasi Masyarakat.

Upaya yang dilakukan oleh DPRD Kabupaten Probolinggo dalam meminimalisasi adanya penyimpangan pelaksanaan APBD, dengan cara melakukan serap aspirasi masyarakat, karena peran serta masyarakat sangat penting dalam mewujudkan pemerintahan yang baik khususnya dalam penyelenggaraan pemerintahan.

Peran serta masyarakat sebagaimana dimaksud dalam hal ini adalah peran aktif masyarakat untuk ikut serta mewujudkan penyelenggaraan pemerintahan yang baik dan bersih, bebas dari korupsi, kolusi, nepotisme, yang dilaksanakan dengan mentaati norma hukum, moral dan sosial yang berlaku dalam masyarakat dan sekaligus melaporkan bila ada penyimpangan anggaran yang dilakukan oleh pemerintah.(Deddy Supriadi, 2002)

Upaya yang harus dilakukan adalah dengan menjalin hubungan harmonis dengan masyarakat, kemudian melakukan belusukan kepada setiap daerah-daerah di Kabupaten Probolinggo, dan selalu melakukan tindakan terhadap aspirasi masyarakat tersebut, agar tercipta hubungan yang harmonis dan menjadi pemerintahan yang bersih.

3) Mengontrol Peran Eksekutif.

Peran Eksekutif dan DPRD dalam menjalankan APBD adalah melakukan Musyawarah/hearing yang dilakukan untuk membicarakan kebutuhan Anggaran Kabupaten selama 1 Tahun dan setiap 3 bulan sekali di adakan musyawarah untuk membahas anggaran kabupaten apakah sudah berjalan efektif, efisien dan tepat sasaran.

Kewenangan DPRD juga mengontrol kinerja eksekutif agar terwujud good govermance seperti yang diharapkan rakyat. Demi mengurangi beban masyarakat, DPRD dapat menekan eksekutif untuk memangkas biaya yang tidak 
perlu, dalam memberikan pelayanan kepada warganya. (Syamsuddin Haris, 2005). Pelaksanaan pengawasan dengan cara mengontrol peran eksekutif dalam penyaluran APBD memang harus dilakukan.

\section{Tahap Pertanggungjawaban}

Pada tahap ini kepala daerah menyampaikan Ranperda tentang pertanggung jawaban pelaksanaan APBD kepada DPRD berupa laporan keuangan yang telah diperiksa oleh Badan Pemeriksaan Keuangan paling lambat enam bulan setelah tahun anggaran berakhir. Laporan keuangan tersebut sekurangkurangnya meliputi realisasi APBD, neraca, laporan arus kas, dan catatan atas laporan keuangan. Laporan keuangan tersebut disusun dan disajikan sesuai dengan standar akuntansi pemerintahan yang ditetapkan dengan peraturan pemerintah. (Siswanto Sunarto, 2012)

Menurut Drs. H. Wahid Nurrahman, M.Si dengan mengadakan laporan pertanggung jawaban setiap tahunnya, maka akan terlihat bagaimana APBD itu mengalir sesuai dengan program pemerintah atau sebaliknya.

Selama beberapa tahun kebelakang, PAD kabupaten Probolinggo terus meningkat itu membuktikan bahwa kinerja DPRD Kabupaten Probolinggo berjalan dengan baik, karna kenaikan PAD menunjukkan bahwa DPRD telah menciptakan suatu inovasi baru.

\section{Faktor Pendukung dan Penghambat dalam Upaya Optimalisasi Pengawasan Pelaksanaan APBD}

Pengendalian (control) adalah mekanisme yang dilakukan oleh pihak eksekutif (pemerintah Daerah) untuk menjamin dilaksanakanya sistem dan kebijakan manajemen sehingga tujuan organisasi dapat tercapai. Pemeriksaan Audit merupakan kegiatan oleh pihak yang memiliki independensi dan memiliki kompetensi profesional untuk memeriksa apakah hasil kinerja pemerintah daerah telah sesuai dengan standar atau kriteria yang ada.

Pengawasan merupakan salah satu fungsi pokok yang harus dilaksanakan dalam suatu kerja sama agar kesinambungan di suatu kegiatan dapat terjaga 
sehingga sasaran dan tujuan yang telah ditetapkan dapat tercapai, selain itu pengawasan dilaksanakan untuk mengetahui adanya penyimpangan dalam suatu pekerjaan. Pengawasan adalah tugas dan wewenang DPRD yang bersifat politisi (terhadap kebijakan) dan bukan merupakan pemeriksaan, sedangkan pemeriksaan merupakan fungsi dan tugas aparat pengawasan fungsional pemerintah (Djumanha, 2007:45).

\section{1) Faktor penghambat dalam Upaya Optimalisasi Pengawasan Pelaksanaan} APBD Tahun 2016

Menurut hasil wawancara dengan Drs H. Wahid N. M,SI selaku wakil ketua DPRD, ada beberapa kendala dan hambatan yang dialami oleh DPRD kabupaten Probolinggo, yaitu Kelemahan internal di DPRD. termasuk kurangnya Sumber Daya Manusia, mengingat Kabupaten Probolinggo yang sangat luas daerahnya dengan penduduk yang sangat padat, juga keterbatasan kualitas sumber daya manusia, permasalahan yang berhubungan dengan anggaran juga masalah-masalah teknis yang datang baik dari internal maupun eksternal.

Keterbatasan sumber daya manusia yang ahli dalam hal pengawasan terhadap APBD, kondisi itu menjadi hal yang sangat memprihatinkan apabila dewan keliru dalam memberikan penilaan terhadap kinerja eksekutif apalagi menyangkut pengelolaan keuangan daerah yang sangat rentan terhadap penyelewengan.

Meskipun begitu, DPRD kabupaten Probolinggo tetap berusaha untuk terus meningkatkan kinerjanya dalam menjalankan tugas dan fungsinya sebagai Wakil Rakyat dengan baik. Perlu menanamkan kesadaran dan pengetahuan tentang pentingnya kedisiplinan didalam menjalankan tugas dan kedudukan dan posisinya di DPRD didapat untuk mewakili suara rakyat dan membantu mensejahterakan rakyat sehingga apa yang akan dilakukan oleh DPRD berorientasi untuk kepentingan rakyat.

Faktor lain yang menjadi penghambat adalah kurangnya melibatkan partisipasi aktif dari masyarakat dalam penyusunan dan pengawasan APBD, sehingga kebutuhan masyarakat sering terabaikan. 


\section{2) Faktor Pendukung dalam Upaya Optimalisasi Pengawasan Pelaksanaan APBD Tahun 2016}

Tetapi untuk meminimalisasikan suatu penghambat dalam proses pembangunan system pengawasan yang dilakukan oleh DPRD kabupeten Probolinggo, DPRD memiliki suatu perangkat yaitu komisi-komisi sesuai bidangnya, DPRD memiliki Komisi diantaranya; Komisi A dalam bidang Pemerintahan dan Perundang-undangan, Komisi B dalam bidang Perekonomian dan Keuangan, Komisi C dalam bidang Pembangunan, Dan Komisi D dalam bidang Kesejahteraan Rakyat

Masing masing komisi diatas di optimalkan untuk melakukan pengawasan. Selain komisi DPRD kabupaten Probolinggo juga membentuk Panitia Khusus apabila ada permasalahan yang mendesak dalam rangka pengawasan. Koordinasi dengan Dinas, Bupati, dan Perangkat bupati dibawahnya juga dilakukan untuk mengatasi faktor-faktor penghambat.

Selain itu juga adanya pengawasan lembaga intern dari pemerintah pusat seperti Badan pengawas keuangan dan pembangunan (BPKP) dan Badan Pengawas Daerah (Bawasda) yang merupakan lembaga intern yang membantu DPRD dalam Pemeriksaan keuangan daerah. Peran kedua lembaga intern ini untuk mengantisipasi kelemahan ataupun kendala-kendala yang ada dalam pengawasan yang dilakukan oleh DPRD. Pengawasan yang dilakukan pemerintah pusat hanya menekankan pada aspek pengawasan represif guna lebih memberi kebebasan kepada daerah otonom dalam mengambil keputusan, sehingga peran legislatif daerah dalam melaksanakan fungsi pengawasannya terhadap pelaksanaan pemerintah daerah dapat berjalan dengan baik.

\section{Kesimpulan}

Peran DPRD Kabupaten Probolinggo dalam melaksanakan fungsi pengawasan terhadap pelaksanaan Anggaran Pendapatan dan Belanja Kabupaten Probolinggo Tahun 2016 sudah berjalan dengan baik. Fungsi pengawasan ini merupakan tanggung jawab yang harus dilakukan agar dapat mengawasi dan 
mengontrol berjalannya optimalisasi kinerja Pemerintah Kabupaten Probolinggo untuk memajukan dan mensejahterakana masyarakat Kabupaten Probolinggo. Fungsi pengawasan ini menunjukkan terwujudnya dalam tata pemerintahan. Dimana DPRD sebagai unsur penyelenggara pemerintahan daerah telah menjalankan tugas pengawasan. Salah satu indikator keberhasilan dalam pengawasan ini adalah adanya peningkatan Pendapatan Asli Daerah (PAD) dari tahun ke tahun.

Selain itu DPRD Kabupaten Probolinggo juga mengalami beberapa kendala dalam pengawasan seperti halnya faktor yang terjadi di dalam lembaga dan di luar lembaga DPRD sendiri, keterbatasan kualitas Sumber daya manusia, terbatasnya fasilitas dan sarana. Tetapi untuk meminimalisasikan suatu penghambat DPRD Kabupaten Probolinggo memiliki suatu perangkat komisi sesuai bidangnya yang di optimalkan untuk melakukan pengawasan, Selain itu juga adanya pengawasan lembaga intern dari pemerintah pusat seperti Badan pengawas keuangan dan pembangunan (BPKP) dan Badan Pengawas Daerah (BAWASDA) yang merupakan lembaga intern yang membantu DPRD dalam Pemeriksaan keuangan daerah.

\section{DAFTAR PUSTAKA}

Bratakusumah, Deddy Supriady dan Solihin, Dadang. (2002), Otonomi Penyelenggaraan Pemerintahan Daerah. Jakarta : PT. Gramedia Pustaka Utama

Budiyono. (2013). Pelaksanaan, Fungsi Pengawasan DPRD Terhadap Pemerintah Daerah Dalam Rangka Mewujudkan Good Governance. Fiat Justitia, Jurnal Ilmu Hukum Vol.7(No.1 Januari-April 2013), pp.1-12.

Haris, Syamsudin. (2005). Desentralisasi dan Otonomi Daerah, Jakarta : LIPI Press

Hidayat, Komaruddin dan Azra, Azyumardi. (2008), Pendidikan Kewarganegaraan, cet. III, Jakarta: Kencana 
Nurhemi \& Suryani R, Guruh. (2015). Dampak Otonomi Keuangan Daerah Terhadap Pertumbuhan Ekonomi di Indonesia, Buletin Ekonomi Moneter dan Perbankan, Vol.18, (No. 2, Oktober 2015), pp.183-206.

Seragih, Bintan Regen. (1984), “Himpunan Undang Undang Dasar, Undang Undang dan Beberapa Peraturan Perundangan Lainnya Tentang Pemerintahan Daerah di Indonesia", Jakarta : Fakultas Hukum Universitas Katolik Atmajaya

Soekarwo. (2003), Berbagai Masalah Keuangan Daerah, Surabaya: Airlangga University Press

Sunarto, Siswanto. (2012). Hukum Pemerintahan Daerah Di Indonesia, cet. VI, Jakarta : Sinar Grafika,

\section{Peraturan Perundang Undangan}

Undang Undang Dasar 1945

Undang-undang Nomor 23 tahun 2014, tentang Pemerintahan Daerah. Peraturan Menteri Dalam Negeri No. 13, Tentang Pengelolaan Keuangan Daerah.

Undang-Undang Nomor 15 tahun 2004 tentang Pemeriksaan atas Pengelolaan dan Tanggung Jawab Keuangan Negara

UU 23 Tahun 2014 tentang Pemerintahan Daerah UU 32 tahun 2004 tentang Pemerintahan Daerah Peraturan Pemerintah No. 25 tahun 2014 tentang Pedoman Penyusunan Peraturan Tata Tertib Dewan Perwakilan Rakyat Daerah. Keputusan Presiden Nomor 74 Tahun 2001 